\title{
Acute Graft Versus Host Disease: A Comprehensive Review
}

\author{
SAMAH NASSEREDDINE ${ }^{1}$, HIND RAFEI $^{1}$, EHAB ELBAHESH $^{2}$ and IMAD TABBARA ${ }^{3}$ \\ ${ }^{1}$ Department of Internal Medicine, George Washington University School of Medicine \\ and Health Sciences, Washington DC, U.S.A.; \\ ${ }^{2}$ Clearview Cancer Institute, Huntsville, AL, U.S.A.; \\ ${ }^{3}$ Division of Hematology/Oncology and GW Cancer Center, \\ George Washington University Medical Faculty Associates, Washington DC, U.S.A.
}

\begin{abstract}
Acute graft versus host disease (aGVHD) remains the second leading cause of death following allogeneic hematopoietic stem cell transplant (AHSCT). Over the last five years, the progress in understanding the pathophysiology of this immune based-process helped redefine graft versus host reaction and opened new possibilities for novel preventive and therapeutic approaches. The evolution in the field of immunology widened the horizons for hematopoietic stem cell transplant leading to the availability of different stem cell sources for potential graft and incorporation of novel conditioning regimens. There is conflicting data about the impact of the graft source and the conditioning regimen used in the process of AHSCT on the incidence of aGVHD. Many studies have reported increased risk of chronic GVHD (cGVHD) and to a less extent aGVHD with the use of peripheral blood stem cell and bone marrow compared to umbilical cord stem cell. The conditioning regimen, either myeloablative, non-myeloablative or reduced intensity may have different impact on the incidence of GVHD. Several preventive modalities have been adopted by different transplant centers but, to date, there is no standardized regimen. As for treatment, immunosuppression using steroids remains the first line of intervention. Several novel therapeutic options are being investigated for treatment of steroid-refractory aGVHD including the use of mesenchymal stem cells, anti thymocyte globulin and
\end{abstract}

This article is freely accessible online.

Correspondence to: Imad Tabbara, MD, Professor of Medicine, Director Blood \& Marrow transplant Program, Division of Hematology/Oncology and GW Cancer Center, George Washington University Medical Faculty Associates, 2150 Pennsylvania Avenue, NW, Washington, DC 20037, U.S.A. Tel: +1 2027412478, Fax: +1 2027412487, email: itabbara@mfa.gwu.edu

Key Words: Acute graft versus host disease, leukemia, allogeneic hematopoietic stem cell transplantation, bone marrow transplantation, review. extra corporeal photophoresis. This review discusses the pathophysiology, risk factors, clinical features, and advances in the diagnosis, prevention and treatment of aGVHD.

Acute graft-versus-host disease (aGVHD) following allogeneic hematopoietic stem cell transplant (AHSCT) is an immune triggered process, leading to profound immune dysregulation and organ dysfunction. Despite pivotal advances, aGVHD remains the second leading cause of death, after disease relapse, in patients undergoing AHSCT (1).

Historically, aGVHD has been defined as a manifestation of rejection occurring in the first 100 days following AHSCT, while chronic GVHD (cGVHD) referred to signs of rejection occurring after 100 days (2). However, a clear distinction between the two conditions has been challenged by the recognition of signs of aGVHD and cGVHD outside of these delineated periods (3). This is thought to be related to the different techniques used in processing stem cells and to the increased use of non-myeloablative regimens and donor lymphocyte infusion (DLI), both of which can potentially delay the appearance of aGVHD (4). In 2014, the NIH released new consensus criteria that refined the definition of both acute and chronic GVHD addressing issues of controversies in the overlap between the two conditions (5).

\section{Pathophysiology}

In the last 20 years, the evolution in clinical immunology brought more insight into the pathogenesis of GVHD and several components were identified to interplay in the mechanism of GVHD: a genetic component favoring the role of HLA compatibility in AHSCT and an immune/biologic component that will be discussed below (6-8).

Initial efforts emphasized the crucial role of mature $\mathrm{T}$ cells in the development of aGVHD; newer studies highlighted the importance of the intestinal epithelium and the role of microbiome in the pathogenesis of $\operatorname{GVHD}(9,10)$. 
Classically, three phases summarize the development of aGVHD: an afferent phase, an efferent phase and an effector phase (11). The afferent phase is a normal but exaggerated inflammatory response leading to activation of antigen presenting cells (APCs). The conditioning regimen used during AHSCT, either ablative or non- myeloablative, leads to target tissue damage. This tissue destruction results in a cytokine activation with excessive release of TNF alpha, IL6 and IL1, which up regulates the expression of MHC antigens and cell surface adhesions molecules on host cells. Intestinal epithelium damage causes release of bacteria and alteration in the gut microbiome triggering propagation of the immune response. Non-genetic triggers are danger associated molecular pattern molecules (DAMPs) and pathogenic associated molecular pattern molecules (PAMPs) that result in perpetual and exaggerated inflammatory response. DAMPs result from non-infectious molecules, while PAMPs have an infectious source. This cytokine storm activates antigen presenting cells. The APCs are from the host hematopoietic cells (dendritic cells, Langerhans cells, and Bcells), non-hematopoietic cells, and donor hematopoietic cells. These APCs present alloantigens which are recognized by the donor T-cells $(12,13)$. This initial phase is followed by T-cell trafficking and expansion, which is the hallmark of the efferent phase. The infused donor T-cells interact with the primed APCs promoting activation of T-cells $(14,15)$. It is thought that CD8 $\mathrm{T}$ cells are predominantly activated by recipient hematopoietic APCs, whereas donor CD4 T cells can also be activated by recipient non-hematopoietic APC within the GI tract (12). Donor APCs may also contribute to GVHD, once primed by alloantigen, donor T-cells undergo proliferation and differentiation such that they secrete or trigger a predictable cytokine profile resulting in the production of IL-2 and IFN- $\gamma$. IL2 controls and amplifies the allogeneic immune response activating further T-cell and NK cell responses (16). The role of IFN- $\gamma$ is poorly understood and paradoxical, but it was found to inhibit GVHD while promoting lymphohematopoietic graft-versus-host reactions (LGVHR) and graft versus leukemia effects (17).

Lastly, the effector phase, a complex cascade of multiple cellular and inflammatory effectors, leading to the escalation of the inflammatory phase promoting further target tissue damage. This phase begins when cytolytic donor effector $\mathrm{T}$ cells cause end-organ damage and continual propagation of this pathway (18). Other effector cells have been implicated and include neutrophils, natural killer cells (NK), NK T cells, and macrophages $(19,20)$.

The importance in the role of tissue damage, described in the afferent phase, in aGVHD has been called into question. Acute GVHD development following DLI does not involve a conditioning regimen, and a reduction of aGVHD is not seen with reduced-intensity conditioning regimens. Although several recent studies continue to support tissue damage as a prominent pathway in the development of gut aGVHD. The gut contains Paneth cells and immune stem cells (ISC). The ISC are responsible for cell renewal, while Paneth cells secrete antimicrobial peptides resulting in regulation of the microbiota. The release of cytokines TNF a, IL-6, and IL-1 following AHSCT damages the ISC and Paneth cells that results in intestinal dysbiosis, which is suspected to be a propagating event in gut aGVHD (10).

As counterparts to the effector cells and of particular interest are cells responsible for suppressing GVHD (21). T regulatory cells ( $\mathrm{T}$ reg), which are $\mathrm{CD} 4^{+} \mathrm{T}$ cells that express low levels of granzyme A and chemokine receptors (e.g. CCR5, CXCR3) (22, 23). Consequently, not only is suppression, but also impairment of target tissue homing of effector cells.

\section{Risk Factors}

Risk factors for the development of aGVHD, other than the extent of HLA disparity, include increased age of both the recipient and the donor, gender disparity, multiparous female donors, ineffective GVHD prophylaxis and the intensity of the transplant conditioning regimen and the source of graft $(24,25)$.

Results were not consistent among studies aiming to determine risk factors associated with aGVHD especially when many of these studies occurred before the era of the 2014 NIH consensus where aGVHD and cGVHD were not identified outside of the 100 days period. Few of the studies reported that the use of peripheral blood stem cells (PBSC) has been associated with increased risk of cGVHD. Anesseti et al. showed that the incidence of aGVHD with the use of PBSC was about the same as in bone marrow (BM) however the incidence of cGVHD was increased by $16 \%$ as compared to bone marrow (26). The use of double unit umbilical cord transplant (dUCB) has been associated with lower incidence of cGVHD but higher incidence of aGVHD (27). Other studies have reported no impact of stem cell source on aGVHD (28-30). A recent study confirmed prior studies by revealing lower incidence of cGVHD in umbilical cord transplant (UCB) but higher incidence of aGVHD in the dUCT. However, this increase in incidence was not reflected in mortality. The authors explain that this better outcome may be related to the responsiveness of these patients to steroids. They also note that the better HLA match is associated with less severe aGVHD in dUCB transplantation (31).

Few studies have evaluated the impact of myeloablative (MA) versus non myeloablative conditioning regimens on the incidence of aGVHD (32-34). Some studies reported increase in incidence and severity of aGVHD in patients receiving full intensity (FI) conditioning regimen.

Risk factors for aGVHD, overall survival, and transplantrelated mortality were evaluated in adults receiving AHSCT between 1999 and 2005 from HLA-identical sibling donors 
Table I. Staging of acute graft versus host disease.

\begin{tabular}{|c|c|c|c|c|}
\hline Clinical Stage & Lower GI & Upper GI & Liver (bilirubin level in $\mathrm{mg} / \mathrm{dl}$ ) & Skin ( $\%$ rash of body surface area BSA) \\
\hline 1 & Diarrhea $<500$ ml/d & Nasuea/vomiting & $2-3$ & $<25 \%$ \\
\hline 2 & Diarrhea 500-1000 ml/day & & $3-6$ & $25-50 \%$ \\
\hline 3 & Diarrhea $1000-1500 \mathrm{ml} /$ day & & $6-15$ & Generalized erythroderma \\
\hline 4 & Diarrhea $>1500 \mathrm{ml} /$ day & & $>15$ & Bullae/Desquamation \\
\hline
\end{tabular}

(SD) or unrelated donors (UD). Patients were randomized to six treatment categories. Patients receiving sibling donor transplants with MA + non Total body irradiation (TBI) + BM and reduced intensity chemotherapy (RIC) + PBSCs had significantly lower risks of grades B-D aGVHD than patients in other treatment categories. Those receiving UD transplants with $\mathrm{MA}+\mathrm{TBI}+\mathrm{BM}, \mathrm{MA}+$ non $\mathrm{TBI}+\mathrm{BM}, \mathrm{RIC}+\mathrm{BM}$, or RIC + PBSCs had lower risks of grades B-D AGVHD than those in other treatment categories. The 5-year probabilities of survival were $46 \% \quad(95 \% \mathrm{CI}=44 \%-49 \%)$ with $\mathrm{SD}$ transplants and $33 \%(95 \% \mathrm{CI}=31 \%-35 \%)$ with URD transplants. Conditioning intensity, TBI and graft source have a combined effect on risk of aGVHD that must be considered in deciding on a treatment strategy for individual patients.

The incidence and severity of aGVHD also appears to increase with pre-transplant comorbidities. In one study of 2,985 patients who underwent myeloablative or reduced intensity conditioning followed by AHCST for myeloid or lymphoid malignancies, the incidence and severity of aGVHD increased with increasing hematopoietic cell transplantation-specific comorbidity index (35).

In a study by Kadhimi et al. the use of the combination of tacrolimus (TAC) and mycophenolate mofetil (MMF) as prophylaxis was associated with high incidence of severe aGVHD and non-relapse mortality especially after transplantations from unrelated donors (36). Better outcome has been noticed with other prophylactic regimens leading to lower incidence of GVHD with the use of ATG (37-39). The role and potential efficacy of antithymocyte globulin (ATG) in patients receiving cord blood transplantation (CBT) remain controversial. A retrospective Chinese study in children with high-risk or advanced hematological malignancies, indicated that the omission of ATG has been associated with faster platelet recovery, a comparable GVHD risk and transplant related mortality, a significantly lower relapse risk, and an improved long-term survival compared to patients who received ATG in the conditioning (40).

\section{Clinical Manifestations and Diagnosis}

Clinical manifestations of aGVHD include specific derangements in the skin, liver and gastrointestinal tract, occasionally the eyes and oral mucosa. It often presents with
Table II. Grading of acute graft versus host disease.

\begin{tabular}{lcccc}
\hline Overall clinical grade & lower GI & Upper GI & Liver & Skin \\
\hline I & 0 & 0 & 0 & $1-2$ \\
II & 1 & 1 & 1 & 3 \\
III & $2-3$ & & $2-4$ & - \\
IV & 4 & & - & 4 \\
\hline
\end{tabular}

skin rash, diarrhea, elevated bilirubin, and it is associated with recurrent infections. The mortality risk varies depending on the stage and grade of aGVHD.

With the use of high-intensity conditioning, aGVHD most commonly occurs 2 to 42 weeks after stem-cell infusion. A hyperacute form of GVHD can occur within the first 2 weeks of AHSCT, and is usually due to significant HLA mismatch or inadequate GVHD prophylaxis, it can be rapidly fatal (41). It is usually grade III to IV and presents with fulminant blistering involvement of the skin associated with pulmonary leak syndrome requiring urgent steroid therapy.

Acute GVHD is clinically graded and staged in severity from grades I to IV depending on the extent of skin, liver, upper GI tract and gut involvement. The most commonly used staging and grading systems are shown in Tables I and II. These staging systems do not include the patient's performance status (42-44).

The diagnosis of aGVHD can be made on clinical grounds in patients presenting with a rash, diarrhea and elevation of bilirubin within the first several weeks of transplant. However, the diagnosis is frequently not straightforward. The role of skin and liver biopsies may be helpful in making the diagnosis but this is still controversial (45). More recently, a panel of plasma biomarkers including IL-2-receptor-a, TNF receptor-1, IL8 , and hepatocyte growth factor has been suggested as a confirmatory tool for the diagnosis of aGVHD at the onset of clinical symptoms and to provide prognostic information independent of GVHD severity (46). The use of biomarkers for the diagnosis of aGVHD remains an active area of investigation. 
Table III. Regimen 1: Use of the combination of Calcineurin inhibitor plus Methotrexate (49, 50).

\begin{tabular}{|c|c|c|c|c|c|}
\hline $\begin{array}{l}\text { Regimen 1: } \\
\text { Calcineurin } \\
\text { inhibitor +MTX }\end{array}$ & Dose & Administration & Duration & Toxicity & Comment \\
\hline Cyclosporin & $\begin{array}{c}\text { CSA initial dose } \\
3 \mathrm{mg} / \mathrm{kg} / \text { day, given } \mathrm{d}-1 \\
\text { prior to graft } \\
\text { Measure concentrations } \\
12 \text { hours after dose. }\end{array}$ & $\begin{array}{l}\text { CSA is initiated IV untill } \\
\text { oral intake is possible. } \\
\text { The oral dose is twice } \\
\text { the IV dose, given in } \\
\text { two daily doses. }\end{array}$ & $\begin{array}{l}\text { Six months in absence } \\
\text { of aGVHD. If No } \\
\text { GVHD, dose } \\
\text { can be tapered } \\
\text { as of } 3 \text { months. }\end{array}$ & $\begin{array}{c}\text { Renal insufficiency, } \\
\text { microangiopathy, } \\
\text { neurological } \\
\text { problems }\end{array}$ & $\begin{array}{c}\text { Target during first } \\
\text { three weeks: } \\
200 \text { to } 300 \mathrm{mg} / \text { Target } \\
\text { until } 3 \text { months following } \\
\text { HSCT: } 100 \text { to } 200 \mathrm{~m} / \mathrm{L}\end{array}$ \\
\hline Methotrexate & $\begin{array}{c}15 \mathrm{mg} / \mathrm{m}^{2} \text { on day }+1 \\
\text { of graft infusion then } \\
10 \mathrm{mg} / \mathrm{m}^{2} \text { on } \\
\text { day } 3,6 \text { and } 11\end{array}$ & IV & on Day 1,3,6 and 11 & $\begin{array}{l}\text { Delayed hematologic } \\
\text { recovery, nephrotoxicity, } \\
\text { hepatic toxicity, } \\
\text { gastrointestinal } \\
\text { mucosal toxicity. }\end{array}$ & $\begin{array}{l}\text { All patients should } \\
\text { receive rescue } \\
\text { leukovorin. }\end{array}$ \\
\hline Tacrolimus & $\begin{array}{l}\text { A loading IV dose } \\
\text { of } 0.02 \mathrm{mg} / \mathrm{kg} / \text { day }\end{array}$ & $\begin{array}{l}\text { IV Switch to oral } \\
\text { when patient is able } \\
\text { to tolerate food }\end{array}$ & $\begin{array}{c}\text { On day-3 to day }-1 \text {, } \\
\text { Continue to d } 100\end{array}$ & $\begin{array}{c}\text { Renal insufficiency, } \\
\text { elevation of bilirubin } \\
\text { levels, hypertension, } \\
\text { hyperglycemia, } \\
\text { neurotoxicity }\end{array}$ & $\begin{array}{c}\text { Adjust dose } \\
\text { according to levels. }\end{array}$ \\
\hline
\end{tabular}

Table IV. Regimen 2: Use of Mycophenolate mofetil and a calcineurin inhibitor (66).

\begin{tabular}{|c|c|c|c|c|}
\hline $\begin{array}{l}\text { Regimen 2: MMF+ } \\
\text { Calcineurin inhibitor }\end{array}$ & Dose & Administration & Duration & Toxicity \\
\hline Mycophenolate Mofetil & $\begin{array}{l}30 \mathrm{mg} / \mathrm{kg} / \text { day orally } \\
\text { in } 2 \text { divided doses }\end{array}$ & IV & $\begin{array}{l}\text { Daily started d } 1 \text { after HSCT for } \\
1 \text { months for patients with sibling } \\
\text { HSCT or } 3 \text { months from UMD }\end{array}$ & $\begin{array}{c}\text { Thrombocytopenia, leucopenia, } \\
\text { high incidence of viral infections, } \\
\text { gastrointestinal upset }\end{array}$ \\
\hline Cyclosporine & $\begin{array}{l}\text { If the oral route is used, the } \\
\text { initial dose is } 12 \mathrm{mg} / \mathrm{kg} / \text { day. }\end{array}$ & IV or oral & $\begin{array}{c}\text { On } \mathrm{d}-1, \text { two doses } \\
\text { every } 12 \text { hours. }\end{array}$ & $\begin{array}{c}\text { Renal insufficiency, microangiopathy, } \\
\text { neurological problems }\end{array}$ \\
\hline
\end{tabular}

\section{Prevention and Treatment}

To date there are no standardized preventive measures for aGVHD. Prophylactic approach is based mainly on immunosuppression either by $\mathrm{T}$ cell depletion or pharmacologically (47). Immunosuppression remains the primary pharmacologic strategy to prevent GVHD. We summarize the suggested regimen in Tables III and IV. The most commonly includes a combination of a calcineurin inhibitor (cyclosporine (Csa) or tacrolimus (TAC)) and a short course of methotrexate (MTX). This regimen was initially established in 1986 (48). Several studies have compared the effectiveness of this combination with either agent alone and showed superiority in prevention of aGVHD in the combination arm $(49,50)$.

Methotrexate has been used since the 1950s as a way of shutting-down $\mathrm{T}$ cells through inhibition of dihydrofolate reductase and production of thymidylate and purines. One recent study showed that the substitution of MTX with corticosteroid in patients who had MTX toxicity, decreased the risk of GVHD however the use of steroids had negative impact on relapse rate and risk of infection hence it did not result in favorable transplant outcome (51).

The backbone of conventional regimens of aGVHD prophylaxis includes 2 drugs: a calcineurin inhibitor plus MTX or MMF or more recently sirolimus (52). The addition of steroids does not confer any beneficial effect (53). Multiple studies have been conducted to compare these regimens but because of the different conditioning regimens used and the diversity of the diseases requiring AHSCT, no definite conclusion has been reached. Cyclosporine monotherapy was inferior to the combination of cyclosporine and methotrexate in regard to the risk of grade II-IV aGVHD. Tacrolimus based calcineurin inhibitor regimen was found to be superior to cyclosporine based regimen with significant reduction in grade II-IV aGVHD but the overall outcome was not significantly different. These results remain controversial and further studies are needed to compare the different regimens used in practice taking in consideration the variation in dosing and duration of treatment $(54,55)$. 
Multiple studies focused on the relationship between drug levels, efficacy, and toxicity profiles. Wingard et al. showed that for both CSA and TAC, higher blood concentrations were associated with an increased incidence of renal dysfunction. In addition, a lower blood concentration of CSA $(<300 \mathrm{ng} / \mathrm{ml})$ was associated with an increased incidence of aGVHD, although this relationship was not statistically significant (56). In 2009, Watanabe et al. published an article studying the effect of tacrolimus level on the incidence of aGVHD Grade II to IV. The cumulative incidence of aGVHD was significantly higher in patients with tacrolimus level less than 7 compared to those with level more than 7 (57). Ganetsky et al. in 2015 found that higher tacrolimus concentrations during the first week after allografting with a reduced-intensity conditioning regimen were associated with significantly reduced risk of grade II-IV aGVHD without increasing risk of relapse. This association was driven by a lower risk of grade II-IV aGvHD in patients with week 1 tacrolimus concentrations $>12 \mathrm{ng} / \mathrm{ml}$ (58). Further studies evaluating optimal dosing strategies are needed to study the incidence of aGVHD with the conventional tacrolimus levels of 5 to 15 versus 10 to $15 \mathrm{ng} / \mathrm{ml}$.

The addition of sirolimus to the GVHD prophylaxis regimen is a good alternative, although it did not improve survival. Cuttler et al. in 2014 revealed that the addition of sirolimus may lead to earlier engraftment and less mucositis (59). Despite the benefit seen in prevention of grade I-II aGVHD, the author did not recommend sirolimus for prophylaxis due to the increased complications like SOS, transplantation associated microangiopathy (TAM), cytopenias, and subsequent infections (60). In 2016, Armand et al. reported that the addition of sirolimus for GVHD prophylaxis in RIC AHSCT is associated with a lower risk of acute GVHD, no improvement in survival and no increased overall toxicity. This regimen is an acceptable option for GVHD prevention in RIC HSCT (61).

The omission of mini-MTX from the TAC/SIR GVHD prophylaxis regimen appears to have no adverse effect on the development of aGVHD. Chen et al. observed that TAC/ $\mu \mathrm{MTX} / \mathrm{MMF}$ is as effective as TAC/MTX and superior to $\mathrm{TAC} / \mathrm{MMF}$ for aGVHD prophylaxis. Although improved toxicity or engraftment was not seen in the TAC/ $\mu \mathrm{MTX} / \mathrm{MMF}$ arm compared to the TAC/MTX arm, the observation of an equivalent incidence of acute and cGVHD, PFS and OS in a higher-risk population suggests that TAC/ $\mathrm{MTX} / \mathrm{MMF}$ may be superior to TAC/MTX. These data challenge the paradigm of completely eliminating MTX from aGVHD prophylaxis regimens. Dose reduction of MTX in combination with MMF is another strategy that may result in improved outcomes (62).

The optimal prophylactic regimen following reducedintensity AHSCT is yet to be established. Solomon et al. in 2014 published an article showing the potential of calcineurin inhibitor-free GVHD prophylaxis with post-transplantation cyclophosphamide and a brief course of sirolimus following reduced-intensity peripheral blood stem cell transplantation. This study was limited by its small size, 26 patients, and chronic GVHD was mainly seen rather than acute GVHD (63).

The use of post-transplantation cyclophosphamide was supported by an initial clinical trial by Fuchs and Luznic at the Sidney Kimmel Comprehensive cancer center at Johns Hopkins in 2010. Their trial showed that high dose Cyclophosphamide can be administered safely following an AHSCT without causing prolonged aplasia and it was uniquely effective in preventing cGVHD and perhaps aGVHD by inducing tolerance in the T cells (64).

More recently, Mielcarek and colleagues released the result of their study utilizing post transplantation cyclophosphamide for the prevention of GVHD. The highdose $\mathrm{Cy}$ in combination with CsA after myeloablative HLAmatched mobilized blood cell transplantation resulted in low rates of both severe aGVHD and cGVHD. In conjunction with high-dose pre-transplant conditioning, the immunosuppressive regimen was safe, and provided effective GVHD-protection while not compromising control of underlying malignancy. If these findings are confirmed in future studies, HLA-matched mobilized blood cell transplantation may gain even greater acceptance and replace marrow as a source of stem cells for most indications (65).

A commonly used regimen in this setting includes a combination of a calcineurin inhibitor with mycophenolate mofetil (MMF) instead of methotrexate as some studies showed less mucositis and more rapid neutrophil engraftment with MMF compared to methotrexate. A Cochrane database systemic review in 2014 showed that a combination of $\mathrm{MMF} /$ calcineurine inhibitor compared to MTX/CI showed a more favorable toxicity profile (66). Multiple studies in 2015 showed that a higher dose of Mycophenolate Mofetil reduced aGVHD in RIC double umbilical cord blood transplants. The use of MMF based GVHD prophylaxis was not inferior to MTX in a myeloablative matched-related donor stem cell transplant (67). In another study, mycophenolate mofetil-based salvage as aGVHD prophylaxis after early discontinuation of tacrolimus and/or sirolimus where they observed acceptable rates of GVHD, overall survival and non-relapse mortality using MMF in patients who discontinued tacrolimus/sirolimus due to toxicities. These data, together with other small studies, support the feasibility and possible value of calcineurine-free MMF-based GVHD prophylaxis for selected patients with high risk for CNI-related toxicities such as those with suboptimal renal function (68).

There exist many preventive strategies that are currently under investigation. One study examined the use of the CCR5 antagonist maraviroc. In this study, 35 high-risk AHSCT recipients had a cumulative incidence of grade IIIV acute GVHD of $14.7 \%$ on day 100 and $23.6 \%$ on day 180. The cumulative incidence of grade III-IV GVHD on day 180 was $5.9 \%$, that was mainly attributed to a very low 
Table V. Ongoing clinical trials addressing the prevention of GVHD in the United States.

\begin{tabular}{|c|c|c|c|c|}
\hline Clinical trial & Name of trial & Investigational agent & Phase & Location \\
\hline NCT02683525 & $\begin{array}{l}\text { Sitagliptin for Prevention } \\
\text { of aGVHD After AHSCT }\end{array}$ & Sitagliptin & $\begin{array}{l}\text { Phase II/Active, } \\
\text { not recruiting }\end{array}$ & United states, Indiana \\
\hline NCT02663622 & $\begin{array}{l}\text { A Phase II Trial of CD24Fc } \\
\text { for Prevention of aGVHD } \\
\text { following Myeloablative AHSCT }\end{array}$ & $\begin{array}{l}\text { Drug: CD24Fc } \\
\text { Drug: Methotrexate } \\
\text { Drug: Tacrolimus } \\
\text { Other: Placebo }\end{array}$ & Phase II & United States, Ohio \\
\hline NCT01713400 & $\begin{array}{c}\text { Tacrolimus, Sirolimus and } \\
\text { Ustekinumab } v s \text {. Tacrolimus and } \\
\text { Sirolimus for the Prevention of aGVHD }\end{array}$ & $\begin{array}{l}\text { Drug: Ustekinumab } \\
\text { Drug: Placebo } \\
\text { Drug: Tacrolimus } \\
\text { Drug: Sirolimus }\end{array}$ & $\begin{array}{l}\text { Phase II/Active } \\
\text { not recruiting } \\
\text { and has results }\end{array}$ & $\begin{array}{l}\text { H. Lee Moffitt } \\
\text { Cancer Center and } \\
\text { Research Institute }\end{array}$ \\
\hline NCT01951885 & $\begin{array}{l}\text { Tac, Mini-MTX, MMF versus } \\
\text { Tac, MTX for GVHD Prevention }\end{array}$ & $\begin{array}{c}\text { Drug: tacrolimus Drug:MTX } \\
\text { Drug:MMF } \\
\text { Drug: MTX (low dose) }\end{array}$ & Phase III & United states, Ohio \\
\hline NCT01926899 & $\begin{array}{l}\text { A Multicenter Phase I Study } \\
\text { Evaluating the Addition of Bortezomib } \\
\text { to an Established aGVHD Prophylaxis } \\
\text { Regimen in Pediatric AHSCT Patients }\end{array}$ & $\begin{array}{l}\text { Drug: Bortezmib } \\
\text { administration }\end{array}$ & Phase I/recruiting & Unites States, Indiana \\
\hline NCT02588339 & $\begin{array}{c}\text { Panobinostat (LBH589): } \\
\text { aGVHD Prevention }\end{array}$ & $\begin{array}{l}\text { Drug: Panobinostat; } \\
\text { Drug: Sirolimus; } \\
\text { Drug: Tacrolimus }\end{array}$ & Phase II & $\begin{array}{c}\text { United States, Florida } \\
\text { Moffitt }\end{array}$ \\
\hline NCT01251575 & $\begin{array}{l}\text { Sirolimus, Cyclosporine, and } \\
\text { Mycophenolate Mofetil in Preventing } \\
\text { GVHD in Treating Patients With } \\
\text { Hematologic Malignancies } \\
\text { Undergoing Donor Peripheral } \\
\text { Blood Stem Cell Transplant }\end{array}$ & $\begin{array}{c}\text { Procedure: AHSCT; } \\
\text { Drug: CSA } \\
\text { Drug: Fludarabine Phosphate; } \\
\text { Other: Laboratory } \\
\text { Biomarker Analysis; } \\
\text { Drug: MMF Procedure: } \\
\text { PBSCT Drug: Sirolimus; } \\
\text { Radiation:TB }\end{array}$ & Phase II & $\begin{array}{l}\text { United states } \\
\text { Denmark }\end{array}$ \\
\hline NCT01527045 & $\begin{array}{l}\text { Donor Atorvastatin Treatment in } \\
\text { Preventing Severe aGVHD After } \\
\text { Non MA PB SCT in Patients With } \\
\text { Hematological Malignancies }\end{array}$ & $\begin{array}{l}\text { Drug: ents With HemaCalcium; } \\
\text { WDrug:uCyclosporineDrug: } \\
\text { yFludarabine MA PB SCT } \\
\text { in Patients With Hematological } \\
\text { MalignanciesAcute+Graft+ } \\
\text { Versus+Host+Di }\end{array}$ & Phase II & $\begin{array}{l}\text { United states } \\
\text { Colorado and } \\
\text { Washington }\end{array}$ \\
\hline NCT01795573 & $\begin{array}{l}\text { Ex-vivo Expanded Donor } \\
\text { Regulatory T Cells for } \\
\text { prevention of aGVHD }\end{array}$ & Biological: Cultured Treg cells & Phase I & United states, Florida \\
\hline
\end{tabular}

incidence of visceral GVHD. At year 1, the rate of nonrelapse mortality was $11.7 \%$ and rates of relapse or infection were not increased (69).

Mesenychymal stem cells may have a preventive effect on GVHD in patients undergoing AHSCT. However, the evidence is weak due to insufficient data (70). Ongoing clinical trials addressing the prevention of aGVHD are summarized in Table V.

In aGVHD, treatment should always be tailored to the severity of the presentation and targeting the symptoms. Initial therapy for aGVHD ranges from a simple observation or a trial of topical corticosteroids (e.g. triamcinolone $0.1 \%$ ) for skin GVHD of stage I or II, observation or a trial of topical corticosteroids (e.g. triamcinolone $0.1 \%$ ) to systemic treatment in patients with grade II-IV aGVHD (47). Treatment consists of continuing the original immunosuppressive prophylaxis and methylprednisolone with the most common starting dose being $2 \mathrm{mg} / \mathrm{kg}$ /day given in 2 divided doses in grade III-IV, while 0.5 to $1 \mathrm{mg} / \mathrm{kg} /$ day for grade II disease. Median time to resolution of aGVHD is 30-42 days. In patients who respond to initial therapy, short-term tapering treatment with prednisone to a cumulative dose of $2,000 \mathrm{mg} / \mathrm{m}^{2}$ is effective and expected to minimize steroid-related complications $(71,72)$.

Alternative therapies for steroid refractory cases include antithymocyte globulin (ATG), cyclosporine alone, mycophenolate mofetil, anti-IL-2 receptor, anti-CD5-specific immunotoxin, pan T-cell ricin A-chain immunotoxin, ABXCBL, etarnercept, infliximab, daclizumab, vilizumab and pentostatin. These agents can be used alone or in combination. There are no sufficient data comparing these regimens. 
The use of mesenchymal stem cell in steroid-refractory aGVHD has been reviewed by Chen et al. Three hundred and one patients from thirteen trials were studied. The authors found that mesenchymal stem therapy as compared to induction therapy may have the best efficacy in patients with lower grade aGVHD and only skin involvement. There was also a trend towards a better clinical response in children compared with adults (73).

Pre-transplant regimen remains the best prophylactic measure in order to avoid development of GVHD. Age, skin involvement, lower aGVHD grade, and the number of stem cell infusions are the main prognostic factors affecting the efficacy of MSC therapy for steroid-refractory aGVHD.

Kitko et al. reported the success of extracorporeal photopheresis for steroid refractory aGVHD and the potential for delivery of ECP in the early pre and post-transplant periods that shows promise as a less immunosuppressive strategy to reduce rates of aGVHD (74).

\section{References}

1 Pasquini M, Wang Z, Horowtiz MM and Gale RP: 2013 report from the Center for International Blood and Marrow Transplant Research (CIBMTR): current uses and outcomes of hematopoietic cell transplants for blood and marrow disorders Clin Transpl 2010: 187-197, 2013.

2 Billingham RE: The biology of graft-versus-host reactions. Harvey Lectures 62: 21-78, 1966-97.

3 Filipovich AH, Weisdorf D, Pavletic S, Socie G, Wingard JR , Lee SJ, Martin P, Chien J, Przepiorka D, Couriel D, Cowen EW, Dinndorf E, Farrell A, Hartzman R, Henslee-Downey J, Jacobsohn D, McDonald G, Mittleman B, Rizzo JD, Robinson M, Schubert M, Schultz K, Shulman H, Turner M, Vogelsang M and Flowers M: National Institutes of Health Consensus Development Project on Criteria for Clinical Trials in Chronic Graft-versus-Host Disease: I. Diagnosis and Staging Working Group Report. Biol Blood Marrow Transpl 11(12): 945-956, 2005.

4 Mielcarek M: Graft-versus-host disease after nonmyeloablative versus conventional hematopoietic stem cell transplantation. Blood 102(2): 756-762, 2003.

5 Pavletic SZ, Vogelsang GB and Lee SJ: 2014 National Institutes of Health Consensus Development Project on Criteria for Clinical Trials in Chronic Graft-versus-Host Disease: Preface to the Series. Biol Blood Marrow Transpl 21(3): 387-388, 2015.

6 Holtan SG, Pasquini M and Weisdorf DJ: Acute graft-versushost disease: a bench-to-bedside update. Blood 124(3): 363-373, 2014.

7 Ferrara JL: Pathogenesis of Acute Graft-Versus-Host Disease: Cytokines and Cellular Effectors. J Hematother Stem Cell Res 9(3): 299-306, 2000.

8 Sun Y, Tawara I, Toubai T and Reddy P: Pathophysiology of acute graft-versus-host disease: recent advances. Transl Res 150(4): 197-214, 2007.

9 Qayed M and Horan J: The Role of Intestinal Microbiota in Graft versus Host Disease. Mini Rev Med Chem 16(3): 193-199, 2015.
10 Teshima T, Reddy P and Zeiser R: Reprint of: Acute graftversus-host disease: novel biological insights. Biol Blood Marrow Transplant 22(1): 11-16, 2016.

11 Ball LM and Egeler RM: Acute GvHD: pathogenesis and classification. Bone Marrow Transplant 41: S58-64, 2008.

12 Blazar BR, Murphy WJ and Abedi M: Advances in graft-versushost disease biology and therapy. Nat Rev Immunol 12(6): 443458, 2012.

13 Paczesny S, Hanauer D, Sun Y and Reddy P: New perspectives on the biology of acute GVHD. Bone Marrow Transplant 45(1): $1-11,2009$

14 Sackstein R: A Revision of Billingham's Tenets: The central role of lymphocyte migration in acute graft-versus-host disease. Biol Blood Marrow Transplant 12(1): 2-8, 2006.

15 Wysocki CA: Leukocyte migration and graft-versus-host disease. Blood 105(11): 4191-4199, 2005.

16 Via CS and Finkelman FD: Critical role of interleukin-2 in the development of acute graft-versus-host disease. Int Immunol 5(6): 565-572, 1993.

17 Wang $\mathrm{H}$ and Yang Y-G: The complex and central role of interferon- $\gamma$ in graft-versus-host disease and graft-versus-tumor activity. Immunol Rev 258(1): 30-44, 2014.

18 Morris GP, Uy GL, Donermeyer D, Dipersio JF and Allen PM: Dual Receptor $\mathrm{T}$ Cells mediate pathologic alloreactivity in patients with acute graft-versus-host disease. Sci Transl Med 5(188): 188ra74, 2013.

19 Ghayur T, Seemayer TA, Kongshavn PA, Gartner JG and Lapp WS: Graft-versus-host reactions in the beige mouse. Transplantation 44(2): 261-266, 1987.

20 Tanaka M, Kobayashi S, Numata A, Tachibana T, Takasaki H, Maruta A, Ishigatsubo $\mathrm{Y}$ and Kanamori $\mathrm{H}$ : The impact of the dose of natural killer cells in the graft on severe acute graftversus-host disease after unrelated bone marrow transplantation. Leuk Res 36(6): 699-703, 2012.

21 Beres AJ and Drobyski WR: The role of regulatory T cells in the biology of graft versus host disease. Front Immunol 4: 163, 2013.

22 Vignali DAA,Collison L and Workman CJ: How regulatory T cells work. Nat Rev Immunol 8(7): 523-532, 2008.

23 Sawitzki B, Brunstein C, Meisel C, Schumann J, Vogt K, Appelt C, Curtsinger JM, Verneris MR, Miller JS, Wagner JE and Blazar BR: Prevention of graft-versus-host disease by adoptive $\mathrm{T}$ regulatory therapy is associated with active repression of peripheral blood Toll-like receptor 5 mRNA expression. Biol Blood Marrow Transplant 20(2): 173-182, 2014.

24 Nash RA, Pepe MS, Storb R, Longton G, Pettinger M, Anasetti C, Appelbaum FR, Bowden RA, Deeg HJ and Doney K: Acute graft-versus-host disease: analysis of risk factors after allogeneic marrow transplantation and prophylaxis with cyclosporine and methotrexate. Blood 80(7): 1838-1845, 1992.

25 Gale RP, Bortin MM, Bekkum DW, Biggs JC, Dicke KA, Gluckman E, Good RA, Hoffmann RG, Kay HE, Kersey JH and Marmont A: Risk factors for acute graft-versus-host disease. $\mathrm{Br}$ J Haematol 67(4): 397-406, 1987.

26 Anasetti C, Logan BR, Lee SJ, Waller EK, Weisdorf DJ, Wingard JR, Cutler CS, Westervelt P, Woolfrey A, Couban S and Ehninger G: Peripheral-blood stem cells versus bone marrow from unrelated donors for the blood and marrow transplant cinical trials network. N Engl J Med 367(16): 14871496, 2012. 
27 Lee SE, Cho BS, Kim JH, Yoon JH, Shin SH, Yahng SA, Eom KS, Kim YJ, Kim HJ, Lee S and Min CK: Risk and prognostic factors for acute GVHD based on NIH consensus criteria. Bone Marrow Transplant 48(4): 587-592, 2012.

28 Flowers ME, Inamoto Y, Carpenter PA, Lee SJ, Kiem HP, Petersdorf EW, Pereira SE, Nash RA, Mielcarek M, Fero ML and Warren EH: Comparative analysis of risk factors for acute graft-versus-host disease and for chronic graft-versus-host disease according to National Institutes of Health consensus criteria. Blood 117(11): 3214-3219, 2011.

29 Gupta A, Punatar S, Gawande J, Mathew L, Bagal B, Kannan S and Khattry N: Risk Factors, Pattern and clinical outcome of acute graft versus host disease in acute leukemia patients undergoing allogeneic stem cell transplant. Indian J Hematol Blood Transfus 31(4): 404-412, 2015.

30 Lazaryan A, Weisdorf DJ, DeFor T, Brunstein CG, MacMillan ML, Bejanyan N, Holtan S, Blazar BR, Wagner JE and Arora M: Risk factors for acute and chronic graft-versus-host disease after allogeneic hematopoietic cell transplantation with umbilical cord blood and matched sibling donors. Biol Blood Marrow Transplant 22(1): 134-140, 2016.

31 Mielcarek M: Graft-versus-host disease after nonmyeloablative versus conventional hematopoietic stem cell transplantation. Blood 102(2): 756-762, 2003.

32 Mielcarek M and Storb R: Graft- vs.-host disease after nonmyeloablative hematopoietic cell transplantation. Leuk Lymphoma 46(9): 1251-1260, 2005.

33 Liu H, Zhai X, Song Z, Sun J, Xiao Y, Nie D, Zhang Y, Huang F, Zhou H, Fan Z and Tu S: Busulfan plus fludarabine as a myeloablative conditioning regimen compared with busulfan plus cyclophosphamide for acute myeloid leukemia in first complete remission undergoing allogeneic hematopoietic stem cell transplantation: a prospective and multicenter study. J Hematol Oncol 6(1): 15, 2013.

34 Sorror ML, Martin PJ, Storb RF, Bhatia S, Maziarz RT, Pulsipher MA, Maris MB, Davis C, Deeg HJ, Lee SJ and Maloney DG: Pretransplant comorbidities predict severity of acute graft-versus-host disease and subsequent mortality. Blood 124(2): 287-295, 2014

35 Al-Kadhimi Z, Gul Z, Chen W, Smith D, Abidi M, Deol A, Ayash L, Lum L, Waller EK, Ratanatharathorn V and Uberti J: High incidence of severe acute graft-versus-host disease with tacrolimus and mycophenolate mofetil in a large cohort of related and unrelated allogeneic transplantation patients. Biol Blood Marrow Transplant 20(7): 979-985, 2014.

36 Al-Kadhimi Z, Gul Z, Rodriguez R, Chen W, Smith D, Mitchell A, Abidi M, Ayash L, Deol A and Lum L, Forman S: Antithymocyte globulin (thymoglobulin), Tacrolimus, and Sirolimus as acute graft-versus-host disease prophylaxis for unrelated hematopoietic stem cell transplantation. Biol Blood Marrow Transplant 18(11): 1734-1744, 2012.

37 Finke J, Bethge WA, Schmoor C, Ottinger HD, Stelljes M, Zander AR, Volin L, Ruutu T, Heim DA, Schwerdtfeger R and Kolbe K: Standard graft-versus-host disease prophylaxis with or without anti-T-cell globulin in haematopoietic cell transplantation from matched unrelated donors: a randomised, open-label, multicentre phase 3 trial. Lancet Oncol 10(9): 855-864, 2009.

38 Kröger N, Solano C and Wolschke C: Antilymphocyte globulin for chronic graft-versus-host disease. N Engl J Med 374(19): 1894-1895, 2016.
39 Zheng C, Luan Z, Fang J, Sun X, Chen J, Li CK, Hu S, Zhu Y and Sun Z: Comparison of conditioning regimens with or without antithymocyte globulin for unrelated cord blood transplantation in children with high-risk or advanced hematological malignancies. Biol Blood Marrow Transplant 21(4): 707-712, 2015.

$40 \mathrm{Hu}$ SW and Cotliar J: Acute graft-versus-host disease following hematopoietic stem-cell transplantation. Dermatol Ther 24(4): 411-423, 2011.

41 Glucksberg HR, Storb R, Fefer A, Buckner CD, Neiman PE, Clift RA, Lerner KG, and Thomas ED: Clinical manifestations of graft-versus-host disease in human recipients of marrow from Hl-A-matched sibling donors. Transplant 18(4): 295-304, 1974.

42 Weisdorf DJ, Snover DC and Haake R: Acute upper gastrointestinal graft-versus-host disease: clinical significance and response to immunosuppressive therapy. Blood 76(3): 624, 1990.

43 Przepiorka D, Weisdorf D and Martin P: Consensus Conference on Acute GVHD Grading. Bone Marrow Transplant 15(6): 825828, 1995.

44 MacMillan ML, Robin M, Harris AC, DeFor TE, Martin PJ, Alousi A, Ho VT, Bolaños-Meade J, Ferrara JL, Jones R and Arora M: A Refined Risk Score for Acute Graft-versus-Host Disease that Predicts Response to Initial Therapy, Survival, and Transplant-Related Mortality. Biol Blood Marrow Transplant 21(4): 761-767, 2015.

45 Kuykendall TD and Smoller BR: Lack of specificity in skin biopsy specimens to assess for acute graft-versus-host disease in initial 3 weeks after bone-marrow transplantation. J Am Acad Dermatol 49(6): 1081-1085, 2003.

46 Paczesny S, Krijanovski OI, Braun TM, Choi SW, Clouthier SG, Kuick R, Misek DE, Cooke KR, Kitko CL, Weyand A and Bickley D: A biomarker panel for acute graft-versus-host disease. Blood 113(2): 273-278, 2009.

47 Ruutu T, Van Biezen A, Hertenstein B, Henseler A, Garderet L, Passweg J, Mohty M, Sureda A, Niederwieser D, Gratwohl A and De Witte T: Prophylaxis and treatment of GVHD after allogeneic haematopoietic SCT: a survey of centre strategies by the European Group for Blood and Marrow Transplantation. Bone Marrow Transplant 47(11): 1459-1464, 2012.

48 Storb R, Deeg HJ, Whitehead J, Appelbaum F, Beatty P, Bensinger W, Buckner CD, Clift R, Doney K, Farewell V and Hansen J: Methotrexate and cyclosporine compared with cyclosporine alone for prophylaxis of acute graft versus host disease after marrow transplantation for leukemia. N Engl J Med 314(12): 729-735, 1986.

49 Chao NJ, Schmidt GM, Niland JC, Amylon MD, Dagis AC, Long GD, Nademanee AP, Negrin RS, O'Donnell MR, Parker PM and Smith EP: Cyclosporine, methotrexate, and prednisone compared with cyclosporine and prednisone for prophylaxis of acute graft-versus-host disease. N Engl J Med 329(17): 12251230, 1993.

50 Ram R, Gafter-Gvili A, Yeshurun M, Paul M, Raanani P and Shpilberg O: Prophylaxis regimens for GVHD: systematic review and meta-analysis. Bone Marrow Transplant 43(8): 643-653, 2008.

51 Kim S-Y, Kim AR, Yoon SY, Cho YH and Lee MH: Substitution of methotrexate with corticosteroid for acute graft-versus-hostdisease prevention in transplanted patients who develop methotrexate toxicity. Biol Blood Marrow Transplant 95(3): 483491, 2016. 
52 Storb R, Antin JH and Cutler C: Should methotrexate plus calcineurin inhibitors be considered standard of care for prophylaxis of acute graft-versus-host disease? Biol Blood Marrow Transplant 16(1): S18-S27, 2009.

53 Ram R, Gafter-Gvili A, Yeshurun M, Paul M, Raanani P and Shpilberg O: Prophylaxis regimens for GVHD: systematic review and meta-analysis. Bone Marrow Transplant 43(8): $643-$ 653,2008

54 Hiraoka A, Ohashi Y, Okamoto S, Moriyama Y, Nagao T, Kodera Y, Kanamaru A, Dohy H and Masaoka T: Phase III study comparing tacrolimus (FK506) with cyclosporine for graftversus-host disease prophylaxis after allogeneic bone marrow transplantation. Bone Marrow Transplant 28(2): 181-185, 2001.

55 Wingard JR, Nash RA, Przepiorka D, Klein JL, Weisdorf DJ, Fay JW, Zhu J, Maher RM, Fitzsimmons WE and Ratanatharathorn V: Relationship of tacrolimus (FK506) whole blood concentrations and efficacy and safety after HLA-identical sibling bone marrow transplantation. Biol Blood Marrow Transplant 4(3): 157-163, 1998.

56 Watanabe N, Matsumoto K, Muramatsu H, Horibe K, Matsuyama T, Kojima S and Kato K: Relationship between tacrolimus blood concentrations and clinical outcome during the first 4 weeks after SCT in children. Bone Marrow Transplant 45(7): 1161-1166, 2009.

57 Ganetsky A, Shah A, Miano TA, Hwang WT, He J, Loren AW, Hexner EO, Frey NV, Porter DL and Reshef R: Higher tacrolimus concentrations early after transplant reduce the risk of acute GvHD in reduced-intensity allogeneic stem cell transplantation. Bone Marrow Transplant 51(4): 568-572, 2015.

58 Cutler C, Logan B, Nakamura R, Johnston L, Choi S, Porter D, Hogan WJ, Pasquini M, MacMillan ML, Hsu JW and Waller EK: Tacrolimus/sirolimus vs tacrolimus/methotrexate as GVHD prophylaxis after matched, related donor allogeneic HCT. Blood 124(8): 1372-1377, 2014.

59 Pulsipher MA, Langholz B, Wall DA, Schultz KR, Bunin N, Carroll WL, Raetz E, Gardner S, Gastier-Foster JM, Howrie and Goyal RK: The addition of sirolimus to tacrolimus/methotrexate GVHD prophylaxis in children with ALL: a phase 3 Children's Oncology Group/Pediatric Blood and Marrow Transplant Consortium trial. Blood 123(13): 2017-2025, 2014.

60 Armand P, Kim HT, Sainvil MM, Lange PB, Giardino AA, Bachanova V, Devine SM, Waller EK, Jagirdar N, Herrera AF and Cutler C: The addition of sirolimus to the graft-versus-host disease prophylaxis regimen in reduced intensity allogeneic stem cell transplantation for lymphoma: a multicentre randomized trial. Br J Haematol 173(1): 96-104, 2016.

61 Chen GL, Zhang Y, Hahn T, Abrams S, Ross M, Liu H and McCarthy PL: Acute GVHD prophylaxis with standard-dose, micro-dose or no MTX after fludarabine/melphalan conditioning. Bone Marrow Transplant 49(2): 248-253, 2013.

62 Solomon SR, Sanacore M, Zhang X, Brown S, Holland K, Morris LE and Bashey A: Calcineurin inhibitor-free graft-versushost disease prophylaxis with post-transplantation cyclophosphamide and brief-course sirolimus following reducedintensity peripheral blood stem cell transplantation. Biol Blood Marrow Transplant 20(11): 1828-1834, 2014.

63 Luznik L and Fuchs EJ: High-dose, post-transplantation cyclophosphamide to promote graft-host tolerance after allogeneic hematopoietic stem cell transplantation. Immunol Res 47(1-3): 65-77, 2010.
64 Mielcarek M, Furlong T, O’Donnell PV, Storer BE, McCune JS, Storb R Carpenter PA, Flowers ME, Appelbaum FR and Martin PJ: Posttransplantation cyclophosphamide for prevention of graft-versus-host disease after HLA-matched mobilized blood cell transplantation. Blood 127(11): 1502-1508, 2016.

65 Kharfan-Dabaja M, Mhaskar R, Reljic T, Pidala J, Perkins JB, Djulbegovic B and Kumar A: Mycophenolate mofetil versus methotrexate for prevention of graft-versus-host disease in people receiving allogeneic hematopoietic stem cell transplantation. Cochrane Database Syst Rev 7: CD010280, 2014.

66 Hamilton BK, Rybicki L, Dean R, Majhail NS, Haddad H, Abounader D, Hanna R, Sobecks R, Duong H, Hill BT and Copelan E: Cyclosporine in combination with mycophenolate mofetil versus methotrexate for graft versus host disease prevention in myeloablative HLA-identical sibling donor allogeneic hematopoietic cell transplantation. Am J Hematol 90(2): 144-148, 2014.

67 Ali H, Palmer J, Eroglu Z, Stiller T, Thomas SH, Khaled S, Shayani S, Parker P, Forman SJ and Nakamura R: Mycophenolate mofetil-based salvage as acute GVHD prophylaxis after early discontinuation of tacrolimus and/or sirolimus. Bone Marrow Transplant 50(2): 307-309, 2014.

68 Reshef R, Luger SM, Hexner EO, Loren AW, Frey NV, Nasta SD, Goldstein SC, Stadtmauer EA, Smith J, Bailey S and Mick $\mathrm{R}$ : Blockade of lymphocyte chemotaxis in visceral graft-versushost disease. N Engl J Med 367(2): 135-145, 2012.

69 Wang L, Gu ZY, Zhao XL, Wei HP, Luo L, Zhao SS, Liu DH, Wang QS and Gao CJ: Role of mesenchymal stem cells in preventing gvhd: a meta-analysis. Zhongguo Shi Yan Xue Ye Xue Za Zhi 23(4): 1125-1132, 2015.

70 Mielcarek M, Storer BE, Boeckh M, Carpenter PA, McDonald GB, Deeg HJ, Nash RA, Flowers ME, Doney K, Lee S and Marr KA: Initial therapy of acute graft-versus-host disease with lowdose prednisone does not compromise patient outcomes. Blood 113(13): 2888-2894, 2008.

71 Mielcarek M, Furlong T, Storer BE, Green ML, McDonald GB, Carpenter PA, Flowers ME, Storb R, Boeckh M and Martin PJ: Effectiveness and safety of lower dose prednisone for initial treatment of acute graft-versus-host disease: a randomized controlled trial. Haematologica 100(6): 842-848, 2015.

72 Chen X, Wang C, Yin J, Xu J, Wei J and Zhang Y: Efficacy of mesenchymal stem cell therapy for steroid-refractory acute graftversus-host disease following allogeneic hematopoietic stem cell transplantation: a systematic review and meta-analysis. PLoS One 10(8): e0136991, 2015.

73 Kitko CL and Levine JE: Extracorporeal photopheresis in prevention and treatment of acute GVHD. Transfus Apher Sci 52(2): 151-156, 2015.

74 Weisdorf D: Graft versus host disease and how to report it. Retrieved April 17, 2014, from http://www.cibmtr.org/Meetings/ Materials/CRPDMC/Documents/2006/november2006/Weisdorf2 _RprtgGVHD.pdf 